\title{
Biological and histopathological evaluation of rice bran oil on hypercholesterolemic rats
}

\author{
Foda, F.A ${ }^{1 *}$, Saad, S.M.M ${ }^{1}$, Abd El-Aleam, I.M ${ }^{1}$ and Sabry , A.M ${ }^{2}$ \\ ${ }^{1}$ Agric.Biochem.Dept.Fac.of Agric., Benha univ., Egypt. \\ ${ }^{2}$ Agric. Res. Center, Giza, Egypt. \\ ${ }^{*}$ Corresponding author's E-mail: farahat.fouda@ fagr.bu.edu.eg
}

\begin{abstract}
The present study was performed to estimate the chemical composition of rice bran and extracted rice bran oil (RBO). Also, physico-chemical parameters and fatty acid composition of RBO were evaluated. In addition, the biological effects of bioactive substances from rice bran oil as additives to the diets at different levels (i.e 10, $15,20,25$ and $30 \%$ ) on lipid profile, liver and kidney functions and histopathological findings of hypercholesterolemic rats. From the obtained results, it could be noticed that the rice bran contains (on dry weight basis) $11.18 \%$ moisture, $45.56 \%$ total carbohydrate, $11.40 \%$ protein, $18.36 \%$ total lipid, $6.31 \%$ crude fiber and $7.21 \%$ ash. The iodine value for the rice bran oil extracted in this study was found to be $102 \mathrm{~g} \mathrm{I} / 100$ g oil extracted, the saponification value was found to be $180 \mathrm{mg} \mathrm{KOH} / \mathrm{g}$. Acid value was $0.6 \mathrm{mg} \mathrm{KOH} / \mathrm{g}$, the refractive index was found to be 1.471 . From the obtained results, it could be noticed that the rice bran oil extracted is dominated by the high percentage of polyunsaturated fatty acids (PUFA) than its saturated counterparts ( $42.74 \%$ oleic acid and $30.81 \%$ linoleic acid). On the other hand, triglycerides, serum total cholesterol, LDL-cholesterol and VLDL-cholesterol of the experimental rats were significantly decreased in all hypercholesterolemic rats fed diets containing different levels of rice bran oil extracted compared with the hypercholesterolemic group. Aspartate transferase (AST) and alanine transferase (ALT) of rats fed diets containing different levels of rice bran oil extracted were significantly lower as compared with rats fed hypercholesterolemic diet. Serum total protein and albumin for hypercholesterolemic rats fed different levels of rice bran oil were significantly higher than those for rats fed hypercholesterolemic diet. On the other hand, the histopathological findings indicated that the addition of rice bran oil at the different above levels to the rats containing cholesterol had slight effect on the microscopical lesions induced by feeding on high cholesterol diet. Finally, from the obtained results and histopathological examination, it could be concluded that the addition of rice bran oil might improve the liver and kidney functions in hypercholesterolemic rats.
\end{abstract}

\section{Keywords:}

\section{Introduction}

Rice bran oil is an excellent source of nutritionally-beneficial compounds, such as sterols, tocopherols and tocotrienols. Rice bran oil's unsaponifiable fraction contains about $43 \%$ phytosterols, $10 \%$ steryl esters and $1 \%$ tocopherol. The free fatty acid (FFA) content of crude rice bran oil is higher than that of many other vegetable oils (Orthoefer, 1996). Rice bran oil (RBO) contains high concentrations of the tocopherol antioxidant compared with other oil seeds. Approximately $1.7 \%$ $(\mathrm{v} / \mathrm{v})$ of the unsaponifiable fraction of $\mathrm{RBO}$ is tocotrienol (De Deckere and Korver, 1996).

Saunders (1990) reported that rice bran typically contained $16-32 \%$ oil. Three major fatty acids, palmitic, oleic and linoleic made up more than $90 \%$ of the total fatty acids.

Rice bran oil is used for both edible and industrial applications. Only high quality rice bran oil is used for food, such as for frying, making mayonnaise and salad dressing. Also, rice bran oil significantly decreases serum cholesterol levels in the body. Industrial applications of rice oil include glycerine and soap production and as a supplement to animal feed (Sugano and Tsuji, 2003).

Rice bran and rice bran oil may lower heart disease risk by decreasing cholesterol synthesis in the body. A breakfast meal containing either rice bran or rice bran oil caused a decrease in the activity of hydroxy methyl-glutaryl-coenzyme A (HMG-COA) reductase, the key enzyme in cholesterol synthesis. The human body normally regulates cholesterol synthesis by decreasing production of cholesterol when dietary cholesterol raises blood cholesterol levels (Hegsted and Kousik 1994).

Orthoefer (1996) reported that rice bran composition amounted to $15 \%$ protein, $18 \%$ oil, $7 \%$ ash, carbohydrates, fiber which were $7 \%$ crud, $28 \%$ total dietary with soluble $2.4 \%$ and insoluble fiber $25.6 \%$.

Tahira et al., (2007) studied the different physico-chemical parameters of rice bran oil. They found that the refractive index, iodine value, and free fatty acid value were recorded as 1.4792, 105 gI2/100g, and $0.07 \%$ (as oleic acid), respectively. The fatty acid profile showed palmitic acid (16.74\%), stearic acid (1.9\%), oleic acid (42.79\%), linoleic acid 
(34.65\%) and linolenic acid $(0.19 \%)$ as major fatty acids.

Rice bran oil contains high levels of unsaturated fatty acid (oleic acid: 52.10 and $34.8 \%$ as well as linoleic acid: 22.1 and $27.1 \%$ ) for the cold and hot extractions, respectively. Major saturated fatty acids present include palmitic acid amounted of 16.2, $14.9 \%$. The peroxide value was $31 \mathrm{meqO} 2 / \mathrm{kg}$ and the iodine value was $72 \mathrm{~g} \mathrm{I} / 100 \mathrm{~g}$ oil, while the saponification value amounted of $156 \mathrm{mg} \mathrm{KOH} / \mathrm{g}$ and the refractive index value was 1.39 obtained for the rice bran oil (Oluremi et al., 2013).

Ha et al., (2005) examined the effect of bioactive substances in rice bran oil (RBO) on lipid levels and lipid peroxidation in serum and liver. They found that the liver cholesterol and triacylglycerol contents were higher in rats fed the high-cholesterol diet than the normal group but significant decrement by RBO supplementation. Similarly, hepatic thiobarbituric acid-reactive substances were increased by a high-cholesterol diet and reduced by RBO supplementation in rats. Serum high-density lipoprotein cholesterol was lowered in the high cholesterol diet group but it was significantly increased in rats of the $\mathrm{RBO}$ group.

The decline in serum cholesterol and low density lipoprotein (LDL) levels noted at 4 weeks from initiation of treatment which were significant for LDL and very low density lipoprotein (VLDL), at the end of the study were significantly lower $(\mathrm{p}<0.05)$ in the RBO group $(104.5$ and $32.5 \mathrm{mg} / \mathrm{dl})$ as compared to the control group (195.7 and $57.3 \mathrm{mg} / \mathrm{dl}$ ) (Tabassum et al., 2005).

Chou et al., (2009) determined the effects of rice bran oil (RBO) on lipid metabolism and insulin resistance in rats with streptozotocin/nicotinamideinduced type 2 diabetes mellitus (T2DM). They found that the RBO group had a lower plasma nonesterified fatty acid concentration, ratio of total to high-density-lipoprotein cholesterol, hepatic cholesterol concentration, and area under the curve for insulin. The RBO group had a higher HDL cholesterol concentration and greater excretion of fecal neutral sterols and bile acid than did the control group. RBO may improve lipid abnormalities, reduce the atherogenic index, and suppress the hyperinsulinemic response in rats with streptozotocin/nicotinamide-induced T2DM. In addition, RBO can lead to increased fecal neutral sterol and bile acid excretion.

The aim of the present investigation was to study the chemical composition and biological effects of rice bran oil (RBO) supplementation at different levels on lipids profile, liver and kidney function of hypercholesterolemic rats.

\section{Materials and Methods}

Rice (Oryza sativa L.) bran was obtained from El-Obour mill, Kafr El-Sheikh Governorate, Egypt. It was stabilized by a heat shock at $105^{\circ} \mathrm{C}$ for 5 min to inhibit the lipases (Connor and Connor, 1972).

Chemical analysis of rice bran and oil extracted:

Rice bran oil was extracted by soaking in hexane at room temperature according to A.O.A.C. (2000). Moisture, ash, crude fiber contents, total lipids, and total nitrogen of the rice bran were determined according to A.O.A.C. (2000). The crude protein was calculated by multiplying the total nitrogen by a factor of 5.9 for all materials.Total carbohydrates were determined according to the method described by Miller (1959). Fatty acid composition of rice bran oil was determined by using HPLC (high performance liquid chromatography) at Regional Center for Food and Feed (FAO and WHO, 1993).

\section{Experimental design:}

A total of thirty-five male albino rats "Webster strain" weighting 110-120 g were used in this study. Rats were obtained from the Farm of the Agricultural Research Center, Giza, Egypt. Rats were fed in the animal house of Crops Technology Department, Food Technology Research Institute (FTRI), Giza, Egypt, under normal healthy conditions for two weeks and fed on basal diet (Lane-Peter and Pearson, 1971).

After feeding on basal diet for two weeks, animals were divided into the following groups Group1: control group.Group 2: rats feeding on hypercholesterolemic diet (HCD). Group 3: hypercholesterolemic rats feeding rice bran oil $10 \%$. Group 4: hypercholesterolemic rats feeding rice bran oil 15\%. Group 5: hypercholesterolemic rats feeding rice bran oil 20\%. Group 6: hypercholesterolemic rats feeding rice bran oil $25 \%$ and Group 7: hypercholesterolemic rats feeding rice bran oil $30 \%$.

Blood samples were collected before treatment (zero time) and then after 49 days from the administration of the different treatments. Blood samples were obtained from the retro-orbital plexus veins from the individual rat by means of fine capillary heparinized tubes. Blood was collected into a plain centrifuge tube for serum preparation and assay of the biochemical parameters of blood including liver, kidney functions and serum cholesterol was carried out. The rats of control and different treatments at the end of the experiment period (49 days) were sacrificed and then mortem findings were recorded.

\section{Biological analysis:}

Serum total cholesterol was determined using the enzymatic method as described by Finely (1978). Assay of serum HDL-cholesterol was carried out according to the method described by Lopez-Virella et al., (1977). Serum LDL-cholesterol and serum VLDL cholesterol were calculated according to Steinberg (1981). The method of Fossati and Preceipe (1982) was used for the determination of 
serum triglycerides. Serum alanine transaminase (ALT) and aspartate transaminase (AST) were determined according to the method described by Reitman and Frankel (1957). Serum total protein was determined using Biuret method performed by (Doumas, 1975). Serum albumin was determined according to the method described by (Doumas et al. 1971). Serum globulin was calculated by subtracting the amount of albumin from total protein. Serum creatinine was measured according to the method of Henery et al., (1974). The enzymatic colorimetric method for urea assay in blood was measured according to the method described by Tabacco et al., (1979).

\section{Histopathological examination:}

Small tissue specimens were collected from liver and kidney of rats in all groups and rapidly fixed in $15 \%$ neutral buffered formalin. After proper fixation, thin paraffin sections were routinely prepared and stained with $\mathrm{H}$ and $\mathrm{E}$ stain for microscopical examination according to Drury and Wallington (1986). These histopathological samples were examined at Faculty of Vet. Med., Benha University.

\section{Statistical analysis of the data:}

The results were analyzed using SPSS 19 program (special package for special sciences).
Differences between means were tested and were significant if $\mathrm{p}$ value $<0.05$ (Compell and Machin, 1993).

\section{Results and Discussion}

\section{Chemical composition of raw materials:}

The chemical composition of rice bran was recorded in Table (1). The composition of rice bran depends on a variety of factors associated with the rice grain itself and the milling process. From the obtained results, it could be noticed that the rice bran contains (on dry weight basis) $11.18 \%$ moisture, $45.56 \%$ total carbohydrate, $11.40 \%$ protein, $18.36 \%$ lipid, $6.31 \%$ crude fiber and $7.21 \%$ ash. These results are in good agreement with those reported by Saunders (1990) and Orthoefer (1996) who found similar observation.

The iodine value for the rice bran oil extracted in this study was found to be $102 \mathrm{~g} \mathrm{I} / 100 \mathrm{~g}$ oil extracted Table (2). The saponification value was found to be $180 \mathrm{mg} \mathrm{KOH} / \mathrm{g}$. Acid value for rice bran oil extracted was $0.6 \mathrm{mg} \mathrm{KOH} / \mathrm{g}$. The refractive index of the rice bran oil extracted was found to be 1.471. These results are in good agreement with those reported by Ramachandran (2001). He reported about the same results.

Table 1. Chemical composition of rice bran:-

\begin{tabular}{lc}
\hline Components & Rice bran on dry weight basis $(\%)$ \\
\hline Moisture & 11.18 \\
Total carbohydrate & 45.56 \\
Crude protein & 11.40 \\
Total lipid & 18.36 \\
Crude fiber & 6.31 \\
\hline Ash & 7.21 \\
\hline
\end{tabular}

Table 2. Physico-chemical parameters of rice bran oil extracted:-

\begin{tabular}{lc}
\hline Characteristic & Value for rice bran oil \\
\hline Iodine value & $102 \mathrm{~g} \mathrm{I} 2 / 100 \mathrm{~g}$ \\
Saponification value & $180 \mathrm{mg} \mathrm{KOH} / \mathrm{g}$ \\
Acid value & $0.6 \mathrm{mg} \mathrm{KOH} / \mathrm{g}$ \\
Refractive index 20 C & 1.471 \\
\hline
\end{tabular}

Fatty acid composition of rice bran oil extracted:The fatty acid profile obtained for the rice bran oil extracted by using HPLC is presented in Table (3) and Fig. (1). From the obtained results, it could be noticed that the rice bran oil is dominated by the high percentage of polyunsaturated fatty acids (PUFA) than its saturated counterparts $(42.74 \%$ oleic acid and $30.81 \%$ linoleic acid). Major saturated fatty acids present include palmitic acid (18.88\%) and myristic acid $(0.32 \%)$, respectively. Also, the oil contains lower percentage of linolenic acid $(0.73 \%)$ and arachidonic acid (0.84\%). Oleic, linoleic and linolenic acids are important essential fatty acids required for growth, physiological functions and body maintenance (FAO and WHO, 1993). The abundance of unsaturated fatty acids in the oil is desirable from nutritional and health points. Also, unsaturated fatty acids consumption will not lead to heart related diseases (Tahira et al., 2007 and Oluremi et al., 2013). 
Effect of different experimental diets on body weight of rats:

The effect of rice bran oil on body weight of the experimental rats after 7 weeks was presented in Table (4). The obtained results showed that there is weight loss in all groups of rats with no significant difference between the different groups. The weight loss in rats fed basal diet was $26.2 \pm 17.43 \mathrm{~g}$ while, it was $26.2 \pm 27.5 \mathrm{~g}$ in rats fed hypercholesterolemic diet. The weight values in hypercholesterolemic rats fed different concentrations of rice bran oil $(5,10,15$, $20,25$ and $30 \%)$ were $30.2 \pm 35.27,28.0 \pm 29.22$, $19.2 \pm 19.8,32.0 \pm 22.63$ and $23.8 \pm 12.07 \mathrm{~g}$, respectively and these results may be due to the differentiation of composition of the diet.

Table 3. Fatty acid composition of oil extracted from rice bran:

\begin{tabular}{cccc}
\hline $\begin{array}{c}\text { Fatty acids } \\
\text { carbon chain }\end{array}$ & Common name & Systematic name & $\begin{array}{c}\text { Relative \% } \\
\text { abundance }\end{array}$ \\
\hline C14:0 & Myristic & Tetradecanoic & 0.32 \\
C16:0 & Palmitic & Hexadecanoic & 18.88 \\
C18:0 & Stearic & Octadecanoic & 1.99 \\
C18:1 & Oleic & Cis-9-octadecenoic & 42.74 \\
C18:2 & Linoleic & Cis,Cis-9,12-octadecdienoic & 30.81 \\
C18:3 & Linolenic & Cis, Cis,Cis-9,12,15 octadectrienoic & 0.73 \\
C20:4 & Arachidonic & 5,8,11,14- eicosatetraenoic & 0.84 \\
C18:1 & Vaccinic & Cis-11-octadecenoic & 1.32 \\
\hline C20:1 & Gadoleic & Cis-9-eicosaenoic & 0.47 \\
\hline
\end{tabular}

Table 4. Effect of experimental diets with rice bran oil on body weight of rats after 7 weeks:-

\begin{tabular}{cccc}
\hline Groups & Initial body weight $(\mathbf{g})$ & Final body weight (g) & Body weight loss (g) \\
\hline G1 & $136.0 \pm 34.36$ & $109.8 \pm 31.95$ & $26.2 \pm 17.43$ \\
G2 & $136.8 \pm 23.38$ & $110.6 \pm 10.04$ & $26.2 \pm 27.5$ \\
G3 & $137.6 \pm 19.93$ & $107.4 \pm 23.01$ & $30.2 \pm 35.27$ \\
G4 & $135.8 \pm 19.68$ & $107.8 \pm 17.71$ & $28.0 \pm 29.22$ \\
G5 & $137.0 \pm 12.83$ & $117.8 \pm 6.83$ & $19.2 \pm 19.8$ \\
G6 & $137.4 \pm 11.50$ & $105.4 \pm 13.97$ & $32.0 \pm 22.63$ \\
G7 & $136.6 \pm 18.50$ & $112.8 \pm 20.90$ & $23.8 \pm 12.07$ \\
\hline L.S.D. at 0.05 & 27.48 & 25.17 & 10.55 \\
\hline G1: Basal diet & G2: Hypercholesterolemic diet (HCD) & G3: Rice bran oil (10\%) in (HCD) \\
G4: Rice bran oil (15\%) in (HCD) & G5: Rice bran oil (20\%) in (HCD) \\
G6: Rice bran oil (25\%) in (HCD) & G7: Rice bran oil (30\%) in (HCD)
\end{tabular}

\section{Effect of different experimental diets on weight of rat organs:}

The weights of heart, liver, kidneys, spleen, lung and testis for the different treatments were presented in Table (5). From these results, it could be observed that the weights of liver, kidneys, heart, spleen and lung had different mean values in rats fed hypercholesterolemic diet than that of rats fed normal diet and these results may be due to the effect of cholesterol on the metabolism in this group. However, HCD rats fed different concentrations of rice bran oil had similar mean values for the weights of liver, kidneys, heart, spleen, lung and testis if compared with the control group. These results were similar to that reported by El-Shirbeeny et al., (2003) and Ha et al., (2005).
Effect of different experimental diets with rice bran oil on cholesterol types and triglycerides after 7 weeks:

The effect of diets containing different levels of rice bran oil on the levels of serum total cholesterol, HDL-C, LDL-C, VLDL-C and triglycerides (lipids profile) were presented in Table (6). The obtained results showed that the mean value of serum total cholesterol for the hypercholesterolemic group was $232.0 \pm 2.95 \mathrm{mg} / 100 \mathrm{ml}$ serum. While , the mean value of serum total cholesterol for rats fed basal diet was $124.2 \pm 1.59 \mathrm{mg} / 100 \mathrm{ml}$ serum. The hypercholesterolemic rats fed diets containing different levels of rice bran oil $(5,10,15,20,25$ and $30 \%$ ) had lower mean values of serum total cholesterol $(174.2 \pm 7.23,162.8 \pm 6.51,154.6 \pm 2.06$, $142.6 \pm 3.56$ and $129.4 \pm 5.34 \mathrm{mg} / 100 \mathrm{ml}$ serum) than 
HCD group respectively. From these results, it could be noted that serum total cholesterol values were significantly decreased in all hypercholesterolemic rats fed diets containing different levels of rice bran oil compared with the high cholesterol group (G2). These reductions of cholesterol may be due to greater excretion of fecal neutral sterols and bile acids due to the effect of bioactive components of rice bran oil.

High density lipoprotein (HDL) cholesterol level was significantly increased in hypercholesterolemic rats fed diets containing different levels of rice bran oil. The mean values of HDL-cholesterol were $39.0 \pm 1.14,51.4 \pm 1.03,55.6$ $\pm 0.81,60.0 \pm 1.00$ and $66.6 \pm 2.58 \mathrm{mg} / 100 \mathrm{ml}$ for hypercholesterolemic rats fed diets containing different levels of rice bran oil, respectively if compared with hypercholesterolemic group (G2) $31.4 \pm 0.51 \mathrm{mg} / 100 \mathrm{ml}$. On the other hand, the mean values of low density lipoprotein (LDL) cholesterol $(157.6 \pm 4.34 \mathrm{mg} / 100 \mathrm{ml})$ for hypercholesterolemic group (G2) were significantly higher than those of the normal health control group (38.2 \pm 2.48 $\mathrm{mg} / 100 \mathrm{ml})$. However, LDL-cholesterol levels for hypercholesterolemic rats fed diets containing different levels of rice bran oil were significantly lower relative to those fed on the high cholesterol diet group. The mean values were 102.6 \pm 7.67, 81.6 $\pm 6.24,71.6 \pm 2.69,55.0 \pm 4.21$ and $37.0 \pm 7.28$ $\mathrm{mg} / 100 \mathrm{ml}$ for G3, G4, G5, G6 and G7, respectively. The levels of VLDL-C were significantly higher in hypercholesterolemic group $(43.0 \pm 1.76 \mathrm{mg} / 100$ $\mathrm{ml}$ ) at the normal health control group ( $24.4 \pm 0.24$ $\mathrm{mg} / 100 \mathrm{ml}$ ). The mean values of triglycerides were lower $(163.0 \pm 2.55,149.0 \pm 1.87,137.0 \pm 1.22$, $138.0 \pm 1.22$ and $125.0 \pm 2.24 \mathrm{mg} / 100 \mathrm{ml})$ in HCD rats fed diets containing different levels of rice bran oil if compared with rats fed hypercholesterolemic diet $(215.0 \pm 8.80 \mathrm{mg} / 100 \mathrm{ml})$ but these values were higher than those of rats fed basal diet $(122.0 \pm 1.22$ $\mathrm{mg} / 100 \mathrm{ml}$ ). Our reported results of the cholesterol and lipid lowering effects of rice bran oil could be interpreted by the ability of rice bran components to inhibit the hydroxy methyl - glutaryl-coenzyme A (HMG-CoA) reductase, a key enzyme in the endogenous synthesis of cholesterol (Tabassum et al., 2005, Foda 2005 and Chou et al., 2009).

Table 5. Effect of experimental diets with rice bran oil on organs weight of rats after 7weeks:-

\begin{tabular}{ccccccc}
\hline \multirow{2}{*}{ Groups } & \multicolumn{5}{c}{ Organ $(\mathbf{g} / \mathbf{1 0 0}$ g body weight $)$} \\
\cline { 2 - 6 } G1 & Heart & Liver & Kidneys & Spleen & Lung & Testis \\
\hline G2 & $0.28 \pm 0.12$ & $3.53 \pm 2.05$ & $0.85 \pm 0.27$ & $0.27 \pm 0.12$ & $0.74 \pm 0.29$ & $1.49 \pm 0.86$ \\
G3 & $0.29 \pm 0.15$ & $3.45 \pm 1.88$ & $0.87 \pm 0.44$ & $0.29 \pm 0.16$ & $0.68 \pm 0.38$ & $1.87 \pm 0.97$ \\
G4 & $0.31 \pm 0.07$ & $4.13 \pm 1.44$ & $0.94 \pm 0.08$ & $0.42 \pm 0.17$ & $0.86 \pm 0.20$ & $1.50 \pm 0.61$ \\
G5 & $0.34 \pm 0.19$ & $3.20 \pm 1.71$ & $0.88 \pm 0.46$ & $0.28 \pm 0.17$ & $0.80 \pm 0.43$ & $1.62 \pm 0.93$ \\
G6 & $0.32 \pm 0.06$ & $2.98 \pm 0.45$ & $1.06 \pm 0.18$ & $0.46 \pm 0.26$ & $0.79 \pm 0.17$ & $1.96 \pm 0.53$ \\
\hline G7 & $0.35 \pm 0.11$ & $3.40 \pm 0.35$ & $1.02 \pm 0.16$ & $0.43 \pm 0.16$ & $0.90 \pm 0.07$ & $1.96 \pm 0.15$ \\
\hline
\end{tabular}

G1: Basal diet G2:Hypercholesterolemic diet (HCD) G3:Rice bran oil (10\%) in (HCD)

G4:Rice bran oil $(15 \%)$ in (HCD)

G6: Rice bran oil $(25 \%)$ in (HCD)
G5:Rice bran oil $(20 \%)$ in $(\mathrm{HCD})$

G7: Rice bran oil (30\%) in (HCD) 
Table (6): Effect of experimental diets with rice bran oil on cholesterol types and triglycerides of rats after 7 weeks:-

\begin{tabular}{|c|c|c|c|c|c|c|c|c|c|c|}
\hline \multirow[b]{2}{*}{ Groups } & \multicolumn{2}{|c|}{ Total Cholesterol } & \multicolumn{2}{|c|}{ HDL.C } & \multicolumn{2}{|c|}{ LDL.C } & \multicolumn{2}{|c|}{ VLDL.C } & \multicolumn{2}{|c|}{ Triacylglyceride } \\
\hline & Z.T. & $\begin{array}{c}\text { After } 7 \\
\text { weeks }\end{array}$ & Z.T. & $\begin{array}{c}\text { After } 7 \\
\text { weeks }\end{array}$ & Z.T. & $\begin{array}{c}\text { After } 7 \\
\text { weeks }\end{array}$ & Z.T. & $\begin{array}{c}\text { After } 7 \\
\text { weeks }\end{array}$ & Z.T. & $\begin{array}{l}\text { After } 7 \\
\text { weeks }\end{array}$ \\
\hline G1 & $122.0 \pm 1.41^{\text {aA }}$ & $124.2 \pm 1.59^{\mathrm{aA}}$ & $61.4 \pm 0.93^{\mathrm{cA}}$ & $61.6 \pm 1.36^{\mathrm{eA}}$ & $35.6 \pm 0.98^{\mathrm{aAt}}$ & $38.2 \pm 2.48^{\mathrm{aA}}$ & $25.0 \pm 0.32^{\mathrm{aA}}$ & $24.4 \pm 0.24^{\mathrm{aA}}$ & $125.0 \pm 1.58^{\mathrm{aA}}$ & $122.0 \pm 1.22^{\text {aA }}$ \\
\hline G2 & $191.2 \pm 7.04^{\mathrm{eA}}$ & $232.0 \pm 2.95^{\mathrm{fB}}$ & $32.6 \pm 0.81^{\text {aA }}$ & $31.4 \pm 0.51^{2 \mathrm{~A}}$ & $126.8 \pm 7.09^{\mathrm{dA}}$ & $157.6 \pm 4.34^{\mathrm{eB}}$ & $31.8 \pm 0.37^{\mathrm{bA}}$ & $43.0 \pm 1.76^{\mathrm{eB}}$ & $159.0 \pm 1.87^{\mathrm{bA}}$ & $215.0 \pm 8.80^{\mathrm{eB}}$ \\
\hline G3 & $183.4 \pm 7.45^{\mathrm{deB}}$ & $174.2 \pm 7.23^{\mathrm{eA}}$ & $37.2 \pm 1.69^{\mathrm{bA}}$ & $39.0 \pm 1.14^{\mathrm{bB}}$ & $112.2 \pm 7.06^{\mathrm{cB}}$ & $102.6 \pm 7.67^{\mathrm{dA}}$ & $34.0 \pm 0.84^{\mathrm{CB}}$ & $32.6 \pm 0.51^{\mathrm{dA}}$ & $170.0 \pm 4.18^{\mathrm{cB}}$ & $163.0 \pm 2.55^{\mathrm{dA}}$ \\
\hline G4 & $178.4 \pm 9.09^{\mathrm{cdB}}$ & $162.8 \pm 6.51^{\mathrm{dA}}$ & $34.8 \pm 1.77^{\mathrm{aA}}$ & $51.4 \pm 1.03^{\mathrm{cB}}$ & $109.8 \pm 8.37^{\mathrm{cB}}$ & $81.6 \pm 6.24^{\mathrm{cA}}$ & $33.8 \pm 1.02^{\mathrm{cB}}$ & $29.8 \pm 0.37^{\mathrm{cA}}$ & $169.0 \pm 5.10^{\mathrm{cB}}$ & $149.0 \pm 1.87^{\mathrm{cAt}}$ \\
\hline G5 & $167.6 \pm 2.11^{\mathrm{bB}}$ & $154.6 \pm 2.06^{\mathrm{dA}}$ & $37.6 \pm 0.98^{\mathrm{bA}}$ & $55.6 \pm 0.81^{\mathrm{dB}}$ & $95.6 \pm 2.11^{\mathrm{bB}}$ & $71.6 \pm 2.69^{\mathrm{cA}}$ & $34.4 \pm 0.98^{\mathrm{cB}}$ & $27.4 \pm 0.24^{\mathrm{bA}}$ & $172.0 \pm 4.90^{\mathrm{cB}}$ & $137.0 \pm 1.22^{\mathrm{bAt}}$ \\
\hline G6 & $171.6 \pm 4.75^{\mathrm{bcB}}$ & $142.6 \pm 3.56^{\mathrm{cA}}$ & $33.4 \pm 1.47^{\mathrm{aA}}$ & $60.0 \pm 1.00^{\mathrm{eB}}$ & $106.4 \pm 6.00^{\mathrm{bcB}}$ & $55.0 \pm 4.21^{\mathrm{bA}}$ & $31.8 \pm 0.8^{\mathrm{bB}}$ & $27.6 \pm 0.24^{\mathrm{bA}}$ & $159.0 \pm 4.00^{\mathrm{bB}}$ & $138.0 \pm 1.22^{\mathrm{bA}}$ \\
\hline G7 & $177.2 \pm 3.02^{\mathrm{bcdB}}$ & $129.4 \pm 5.34^{\mathrm{bA}}$ & $37.2 \pm 1.16^{\mathrm{bA}}$ & $66.6 \pm 2.58^{\mathrm{fB}}$ & $106.6 \pm 2.25^{\mathrm{cB}}$ & $37.8 \pm 7.28^{\mathrm{aA}}$ & $33.4 \pm 0.98^{\mathrm{cB}}$ & $25.0 \pm 0.45^{\text {aAd }}$ & $167.0 \pm 4.90^{\mathrm{cB}}$ & $125.0 \pm 2.24^{\mathrm{aA}}$ \\
\hline \multirow{3}{*}{$\begin{array}{l}\text { LSD at } \\
0.05 \text { for }\end{array}$} & Period & 5.56 & & 1.43 & & 5.85 & & 0.83 & & 4.16 \\
\hline & Group & 10.41 & & 2.67 & & 10.95 & & 1.55 & & 7.77 \\
\hline & $P * G$ & 14.72 & & 3.77 & & 15.48 & & 2.20 & & 10.99 \\
\hline
\end{tabular}

a, b \& c: There is no significant difference ( $P>0.05$ ) between any two means, within the same column have the same superscript letter.

A, B \& C: There is no significant difference $(P>0.05)$ between any two means for the same attribute, within the same row have the same superscript letter.

G1:Basal diet

G2:Hypercholesterolemic diet

G3:Rice bran oil (10\%)

G4:Rice bran oil $(15 \%)$

G5:Rice bran oil (20\%) G6:Rice bran oil (25\%)

G7:Rice bran oil ( $\left.30^{\circ} \%\right)$

Z.T: Zero Time 
Effect of different experimental diets on liver transaminases activity after 7 weeks:

Deterimination of transaminases activity released into the blood is one of the most useful indicators of liver functions. The mean values of liver transaminases activity (AST and ALT) were represented in Table (7) and these values were higher for rats fed hypercholesterolemic diet $(77.5 \pm 2.7$ and $75.3 \pm 4.4 \mathrm{IU} / \mathrm{ml}$ respectively) than that for rats fed basal diet $(29.6 \pm 2.6$ and $17.5 \pm 2.0 \mathrm{IU} / \mathrm{ml}$ respectively). The increment in liver enzymes activity reflected the lesions had been occurred in liver functions after its cellular damage and consequently the elaboration of its intracellular enzymes into the blood stream (Hassan et al., 1994). However, HCD rats fed diets containing different levels of rice bran oil had significantly lower values as compared with rats fed hypercholesterolemic diet. So, from the above mentioned results, rice bran oil led to improve liver functions (El-Shirbeeny et al., 2003).

Table 7. Effect of experimental diets with rice bran oil on transaminases activity of rats after 7 weeks:

\begin{tabular}{ccccc}
\hline \multirow{2}{*}{ Groups } & \multicolumn{2}{c}{ AST $(\mathbf{I U} / \mathbf{m l})$} & \multicolumn{2}{c}{ ALT $(\mathbf{I U} / \mathbf{m l})$} \\
\cline { 2 - 4 } G1 & Z.T. & After 7 weeks & Z.T. & After 7 weeks \\
\hline G2 & $26.4 \pm 0.9$ & $29.6 \pm 2.6$ & $18.5 \pm 2.3$ & $17.5 \pm 2.0$ \\
G3 & $25.8 \pm 2.3$ & $77.5 \pm 2.7$ & $16.9 \pm 2.4$ & $75.3 \pm 4.4$ \\
G4 & $24.3 \pm 1.8$ & $39.4 \pm 1.3$ & $16.9 \pm 1.3$ & $28.2 \pm 2.3$ \\
G5 & $24.6 \pm 3.1$ & $32.4 \pm 1.2$ & $16.5 \pm 0.6$ & $26.9 \pm 1.6$ \\
G6 & $23.6 \pm 3.0$ & $28.1 \pm 0.9$ & $19.2 \pm 2.1$ & $22.7 \pm 2.3$ \\
G7 & $25.4 \pm 2.4$ & $24.2 \pm 3.1$ & $17.6 \pm 1.9$ & $22.3 \pm 1.1$ \\
\hline
\end{tabular}

\begin{tabular}{llcl}
\hline L.S.D. at $\mathbf{0 . 0 5}$ & \multicolumn{2}{c}{$<0.001$} & $<0.001$ \\
\hline G1: Basal diet & G2: Hypercholesterolemic diet (HCD) & G3: Rice bran oil (10\%) in (HCD) \\
G4: Rice bran oil $(15 \%)$ in (HCD) & G5: Rice bran oil (20\%) in (HCD) & G6: Rice bran oil \\
$(25 \%)$ in (HCD) & G7: Rice bran oil $(30 \%)$ in (HCD) & Z.T: Zero Time &
\end{tabular}

Effect of different experimental diets on serum total protein, albumin and globulin after 7 weeks:

The mean values of serum total protein, albumin and globulin (protein profile) were represented in Table (8). Serum total protein for hypercholesterolemic rats fed different levels of rice bran oil $5,10,15,20,25$ and $30 \%$ were found to be $5.6 \pm 0.3, \quad 6.4 \pm 0.4, \quad 6.4 \pm 0.3, \quad 6.8 \pm 0.8$ and $6.9 \pm 0.9$ $\mathrm{mg} / 100 \mathrm{ml}$ serum, respectively. These values were significantly higher than those for rats fed hypercholesterolemic diet $(4.4 \pm 0.3 \mathrm{mg} / 100 \mathrm{ml}$ serum). The highest value of total protein was present in rats fed basal diet $(7.5 \pm 0.2 \mathrm{mg} / 100 \mathrm{ml}$ serum). Also, serum albumin levels were significantly higher in HCD rats fed different levels of rice bran oil than those fed hypercholesterolemic diet. On the other hand, the mean values of serum globulin of HCD rats fed diets with different levels of rice bran oil had a significant increase compared with control group. The lowest value of serum globulin was in rats fed hypercholesterolemic diet $(2.0 \pm 0.4 \mathrm{mg} / 100 \mathrm{ml})$. Albumin/ globulin ratio in HCD rats fed different levels of rice bran oil showed a non significant increase $(1.1 \pm 0.2,1.0 \pm 0.4,1.2 \pm 0.2$, $1.3 \pm 0.5$ and $1.6 \pm 0.6$ ). While, albumin/ globulin ratio of rats fed hypercholesterolemic diet was 1.2 \pm 0.4 . This means that hypercholesterolemic diet influenced on protein profile (El-Shirbeeny et al., 2003 and Foda 2005).

Effect of different experimental diets on kidneys function of rats after 7 weeks:

Blood urea and serum creatinine were considered as indicators of kidneys function. Urea is known to be the major end product of protein metabolism in mammals. Serum creatinine is a guide to the glomerular filteration rate and thus the overall kidneys function (Heibashey and Abdel-Moneim 1999). The mean values of urea and creatinine were found to be $35.8 \pm 3.6$ and $0.8 \pm 0.04 \mathrm{mg} / 100 \mathrm{ml}$ respectively for rats fed basal diet, while the values for rats fed hypercholesterolemic diet were 73.4 \pm 3.0 and $1.9 \pm 0.10 \mathrm{mg} / 100 \mathrm{ml}$, respectively as shown in Table (9). From these results, it could be seen that kidneys function indicators were significantly higher in the hypercholesterolemic group if compared with rats fed basal diet. HCD rats fed diets with different levels of rice bran oil $(5,10,15,20,25$ and 30\%) had significantly lower kidneys function parameters than those of hypercholesterolemic group. These results are in agreement with those reported by ElShirbeeny et al., (2003) and Foda (2005) they reported similar results. 
Table 8. Effect of experimental diets with rice bran oil on total protein, albumin and globulin of rats after 7 weeks

\begin{tabular}{ccccccccc}
\hline \multirow{2}{*}{ Groups } & \multicolumn{2}{c}{ Total protein } & \multicolumn{2}{c}{ Albumin } & \multicolumn{2}{c}{ Globulin } & \multicolumn{2}{c}{ A/G ratio } \\
\cline { 2 - 8 } & Z.T. & $\begin{array}{c}\text { After 7 } \\
\text { weeks }\end{array}$ & Z.T. & $\begin{array}{c}\text { After 7 } \\
\text { weeks }\end{array}$ & Z.T. & $\begin{array}{c}\text { After 7 } \\
\text { weeks }\end{array}$ & Z.T. & $\begin{array}{c}\text { After 7 } \\
\text { weeks }\end{array}$ \\
\hline G1 & $7.3 \pm 0.3$ & $7.5 \pm 0.2$ & $4.5 \pm 0.3$ & $4.3 \pm 0.2$ & $2.8 \pm 0.1$ & $3.3 \pm 0.3$ & $1.6 \pm 0.2$ & $1.3 \pm 0.2$ \\
G2 & $7.5 \pm 0.3$ & $4.4 \pm 0.3$ & $4.3 \pm 0.6$ & $2.4 \pm 0.3$ & $3.3 \pm 0.7$ & $2.0 \pm 0.4$ & $1.4 \pm 0.4$ & $1.2 \pm 0.4$ \\
G3 & $6.8 \pm 0.4$ & $5.6 \pm 0.3$ & $4.5 \pm 0.2$ & $2.9 \pm 0.2$ & $2.3 \pm 0.5$ & $2.7 \pm 0.3$ & $2.0 \pm 0.6$ & $1.1 \pm 0.2$ \\
G4 & $7.3 \pm 0.6$ & $6.4 \pm 0.4$ & $4.5 \pm 0.4$ & $3.0 \pm 0.6$ & $2.8 \pm 0.9$ & $3.4 \pm 0.8$ & $1.8 \pm 0.8$ & $1.0 \pm 0.4$ \\
G5 & $7.3 \pm 0.5$ & $6.4 \pm 0.3$ & $4.5 \pm 0.5$ & $3.5 \pm 0.2$ & $2.8 \pm 0.7$ & $2.9 \pm 0.3$ & $1.7 \pm 0.6$ & $1.2 \pm 0.2$ \\
G6 & $7.1 \pm 0.5$ & $6.8 \pm 0.8$ & $4.2 \pm 0.3$ & $3.7 \pm 0.3$ & $2.9 \pm 0.5$ & $3.1 \pm 0.9$ & $1.5 \pm 0.2$ & $1.3 \pm 0.5$ \\
G7 & $7.4 \pm 0.3$ & $6.9 \pm 0.9$ & $4.6 \pm 0.2$ & $4.1 \pm 0.2$ & $2.8 \pm 0.3$ & $2.8 \pm 0.8$ & $1.7 \pm 0.2$ & $1.6 \pm 0.6$ \\
\hline L.S.D. at & & $<0.001$ & & $<0.001$ & & $<0.05$ & & $>0.05$ \\
0.05 & & & & & &
\end{tabular}

G1: Basal diet $\quad$ G2: Hypercholesterolemic diet (HCD) $\quad$ G3: Rice bran oil (10\%) in (HCD)

G4: Rice bran oil (15\%) in (HCD) G5: Rice bran oil (20\%) in (HCD) G6: Rice bran oil (25\%) in (HCD)

G7:Rice bran oil (30\%) in (HCD) Z.T: Zero Time

Table 9. Effect of experimental diets with rice bran oil on kidney functions of rats after 7 weeks:-

\begin{tabular}{ccccc}
\hline \multirow{2}{*}{ Groups } & \multicolumn{2}{c}{ Blood urea } & \multicolumn{2}{c}{ Serum creatinine } \\
\cline { 2 - 5 } & Z.T. & After 7 weeks & Z.T. & After 7 weeks \\
\hline G1 & $33.0 \pm 4.3$ & $35.8 \pm 3.6$ & $0.8 \pm 0.04$ & $0.8 \pm 0.04$ \\
G2 & $33.0 \pm 3.9$ & $73.4 \pm 3.0$ & $0.8 \pm 0.10$ & $1.9 \pm 0.10$ \\
G4 & $35.0 \pm 4.0$ & $65.2 \pm 2.2$ & $0.9 \pm 0.10$ & $1.4 \pm 0.10$ \\
G5 & $37.0 \pm 4.7$ & $55.4 \pm 3.8$ & $0.8 \pm 0.04$ & $1.3 \pm 0.10$ \\
G6 & $33.0 \pm 4.6$ & $53.6 \pm 4.7$ & $0.8 \pm 0.10$ & $1.3 \pm 0.10$ \\
G7 & $33.0 \pm 5.2$ & $42.0 \pm 3.5$ & $0.8 \pm 0.03$ & $0.9 \pm 0.10$ \\
\hline L.S.D. at 0.05 & $33.8 \pm 6.0$ & $37.0 \pm 3.5$ & $0.8 \pm 0.04$ & $0.8 \pm 0.10$ \\
\hline
\end{tabular}

G1: Basal diet G2: Hypercholesterolemic diet (HCD) G3: Rice bran oil (10\%) in (HCD) G4: Rice bran
oil $(15 \%)$ in $(\mathrm{HCD})$
G5:Rice bran oil (20\%) in (HCD)
G6:Rice bran oil (25\%) in (HCD)

$\mathrm{G} 7:$ Rice bran oil $(30 \%)$ in $(\mathrm{HCD})$ Z.T: Zero Time

\section{Histopathological findings:}

Liver:

\section{Control group:}

The histopathological examination of the rats liver fed on basal diet revealed that the normal hepatic cells were arranged in cords around central veins with normal bile ducts (Fig. 2,a).

\section{High cholesterol group:}

The microscopic examination of the rats liver fed on high cholesterol revealed severe degree of fatty change. The hepatocytes showed the presence of clear vacuoles squeezing the nucleus of hepatocytes to one side giving them Signet - ring appearance (fig. 2b,c). Moreover, severe congestion of the central vein and hepatic sinusoids were also detected. The portal areas showed mild leukocytic infiltration particularly of mononuclear types

Hypercholesterolemic diet with rice bran oil:
Liver of rats fed diets containing $10 \%$ rice bran oil (G3) showed congestion of the central vein and hepatic sinusoids (Fig. 2,d).

The hepatocytes showed degenerative changes in the form of vacuolar and hydropic degeneration. The portal blood vessels showed mild congestion and dilatation. Moreover, the bile duct showed mild thickening of the wall due to mild fibrous tissue proliferation (Fig. 2,e).

Microscopic examination of the liver of rats fed diets containing $15 \%$ rice bran oil (G4) showed severe congestion of the central vein and portal blood vessels (Fig. 2,f). and the liver of rats fed diets containing $20 \%$ rice bran oil (G5) showed mild congestion and dilatation of the central vein and hepatic sinusoids (Fig. 2,g ). The portal area showed normal structure. Examined liver of G6 and G7 (HCD rats fed on diets containing $25 \%$ and $30 \%$ rice bran oil, respectively) showed only congestion of the portal vessels with hydropic degeneration of few hepatic cells (Fig. 2,h). 


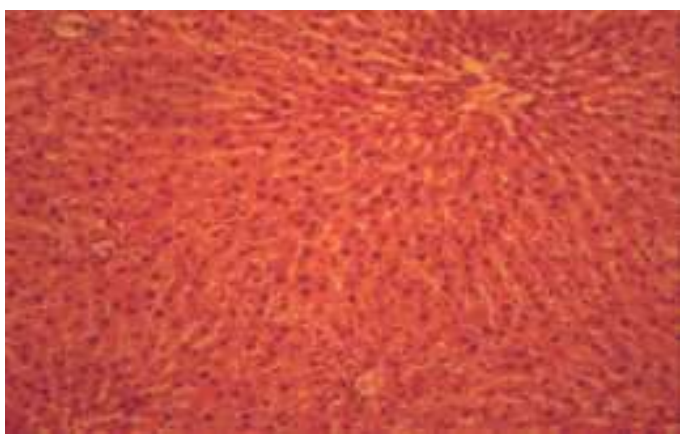

Fig. (2,a): Liver of rat (control group) showing normal histological structure of hepatocytes arranged in cords and bile duct. (H\&E stain X300)

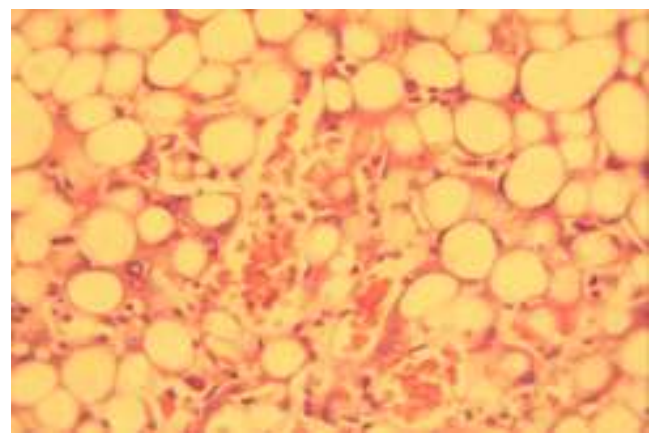

Fig. $(2, \mathrm{c})$ : High power of the previous figure showing signet-ring shape of hepatocytes as the nucleus become flattened and squeezed to one side. (H\&E stain X600)

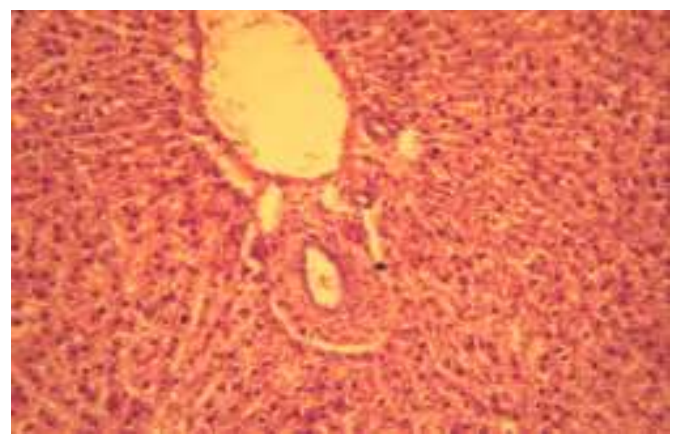

Fig. (2,e): Liver of rat fed diets containing $10 \%$ rice bran oil showing congestion \& dilatation of the portal blood vessels with mild degree of biliary cirrhosis. (H\&E stain X300)

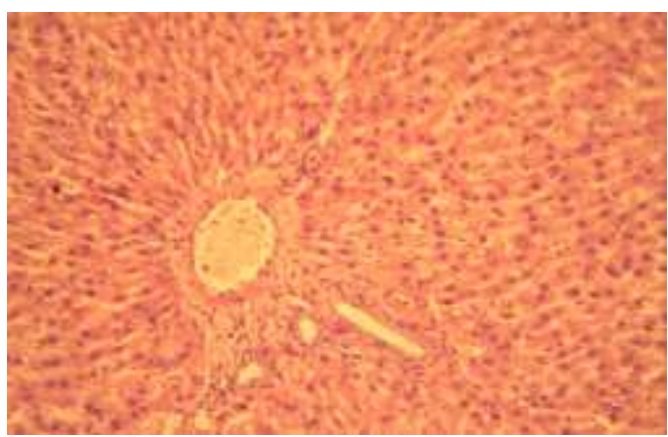

Fig. $(2, \mathrm{~g})$ : Liver of rat fed diet containing $20 \%$ rice bran oil showing mild congestion of the portal blood vessels with mild biliary cirrhosis \& mild degree of degeneration of hepatocytes. (H\&E stain X300)

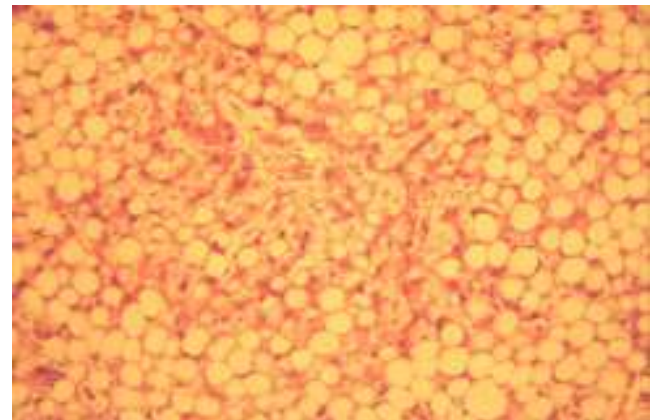

Fig. $(2, b)$ : Liver of rat fed on high cholesterol diet showing severe degree of fatty change of the hepatocytes. (H\&E stain X300)

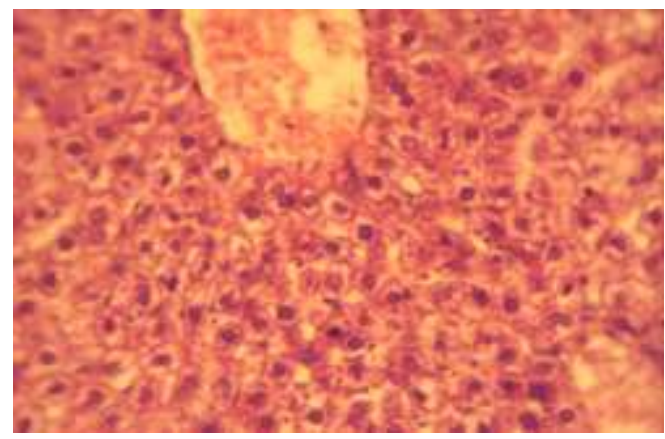

Fig. (2,d): Liver of rat fed diets containing $10 \%$ rice bran oil showing a) congestion of the central vein \& hepatic sinusoids. b) hydropic degeneration of the hepatocytes. (H\&E stain X600)

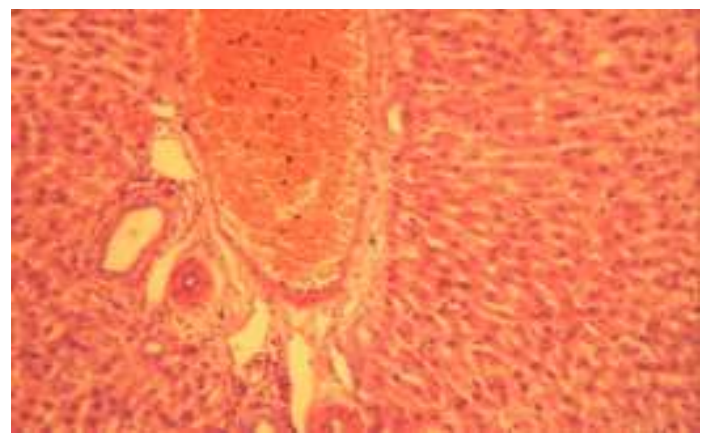

Fig. (2,f): Liver of rat fed diets containing $15 \%$ rice bran oil showing severe congestion of the portal blood vessels. (H\&E stain $\mathrm{X} 300$ )

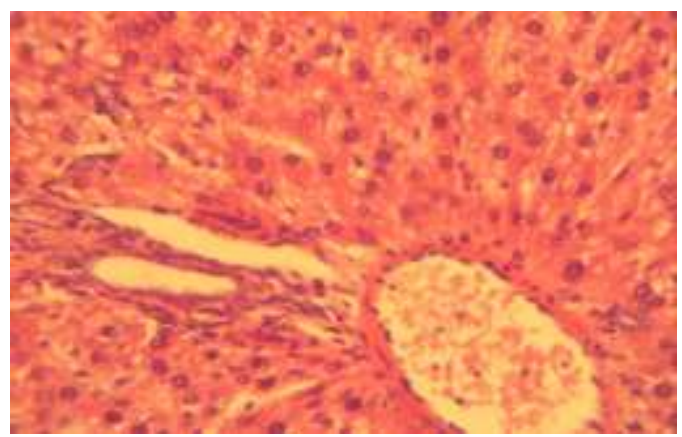

Fig. (2,h): Liver of rat fed diet containing $25 \%$ rice bran oil showing mildest degree of congestion of the portal blood vessels \& vacuolar degeneration of hepatocytes. (H\&E stain X600) 


\section{Kidneys: \\ Control group:}

The histopathological examination of the kidneys of rats fed basal diet revealed normal renal tubules and glomeruli (Fig. 3,a).

\section{High cholesterol group:}

The microscopic examination of the kidneys of rats fed high cholesterol revealed severe congestion of the renal blood vessels and intertubular capillaries. The glomeruli showed severe congestion of the glomerular tuft. Moreover, the renal tubules showed cystic dilation with the presence of eosinophilic debris in their lumens (Fig. 3,b). The renal blood vessels showed perivascular mononuclear cellular infiltration (Fig. 3,c). Hyaline casts was also seen inside the renal tubules.

\section{Hypercholesterolemic diet with rice bran oil:}

Examined kidneys of G3 revealed severe congestion of the glomerular tuft and renal blood vessels as well as intertubular capillaries (Fig. 3,d). The renal tubules showed mild degenerative changes with the presence of eosinophilic debris in their lumens (Fig. 3, e).

The microscopical examination of G4 showed moderate congestion of the renal blood vessels and glomerular tuft. Moreover, perivascular mononuclear cellular infiltration was also seen. The clear microscopical findings were represented by cystic dilatation of the renal tubules in the medulla (Fig. 3,f). Moreover, hyaline casts was seen.

Examined kidneys of G5 revealed mild congestion of the renal blood vessels. Moreover, mild desquamation of the epithelial cell lining of the renal tubules was also detected (Fig. 3,g).

The microscopical examination of G6 and G7 revealed mild congestion of some renal blood vessels (Fig. 3,h).

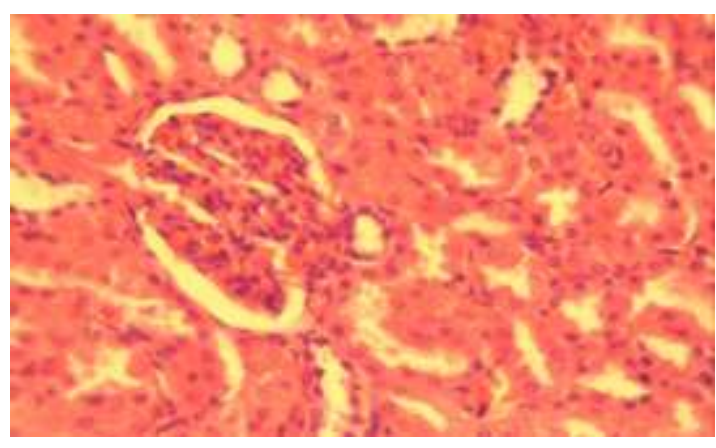

Fig. (3,a): Kidneys of rat (control group) showing normal histological structure. (H\&E stain X300)

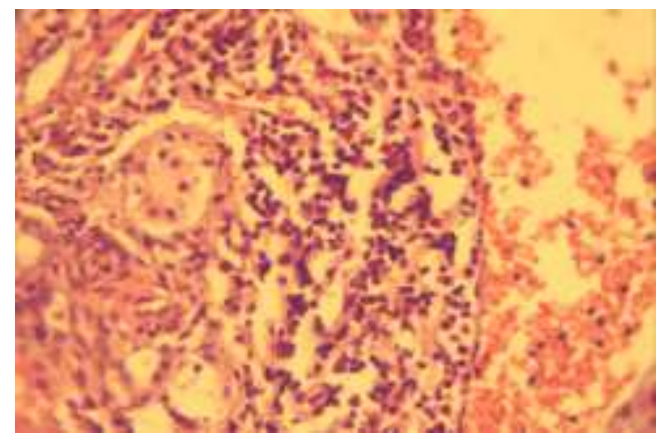

Fig. (3,c): Kidneys of rat fed on high cholesterol diet showing perivascular lymphocytic infiltration. (H\&E stain X600)

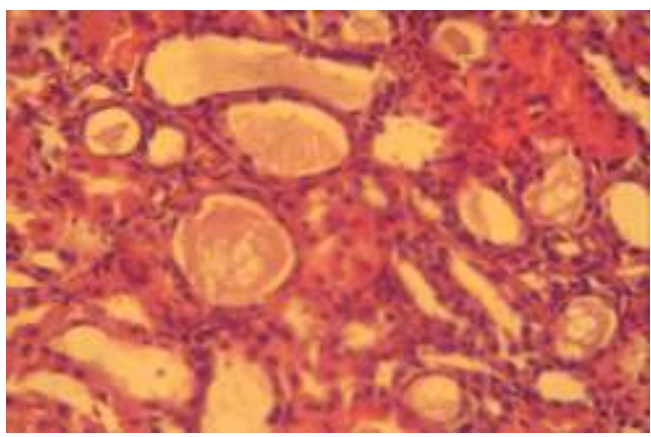

Fig. $(3, b)$ : Kidneys of rat fed on high cholesterol diet showing complete lysis of glomeruli with cystic dilatation of renal tubules. (H\&E stain X300)

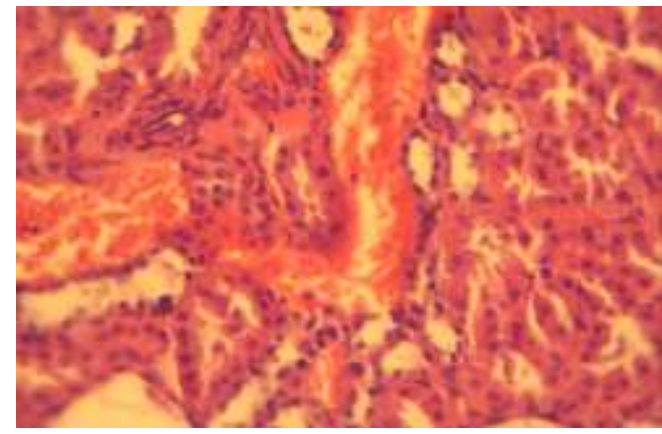

Fig. (3,d): Kidneys of rat fed diets containing $10 \%$ rice bran oil showing severe congestion of the intertubular capillaries. (H\&E stain $\mathrm{X} 600$ ) 


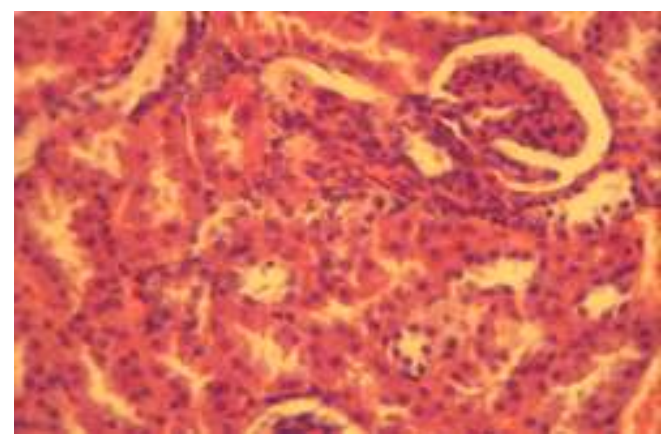

Fig.(3,e): Kidneys of rat fed diets containing $10 \%$ rice bran oil showing mild degenerative changes of the renal tubules. (H\&E stain X300)

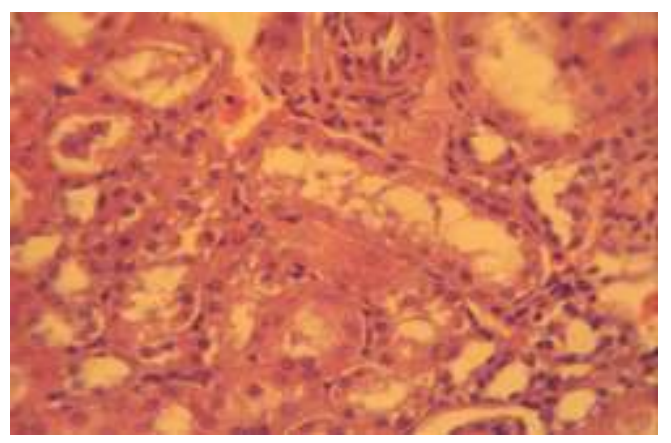

Fig. $(3, \mathrm{~g})$ : Kidneys of rat fed diets containing $20 \%$ rice bran oil showing mild desquamation of the epithelial cell lining of the renal tubules. (H\&E stain X600)

\section{References}

A.O.A.C. (2000): Association of Official Analytical Chemists, Official Methods of Analysis Washington, D.c. $17^{\text {th }}$ Ed. U.S.A.

Chou, T.W., Ma, C.Y., Cheng, H.H., Chen, Y.Y. and Lai1, M.H. (2009): A rice bran oil diet improves lipid abnormalities and suppresses hyperinsulinemic responses in rats with streptozotocin/ nicotinamide-induced type 2 diabetes. Clin. Biochem. Nutr., 45, 29-36.

Compell, M. and Machin, L. (1993): Medical statistics: A common approach. Second edition John Weily and Sons Chichester, New York, Brisbane, Toranta and Singapora.

Connor, W.E. and Connor, S.L. (1972): Diet and Prevention of Coronary Heart Disease and Cancer B. Hallgren (ed.). Raven press, New York, p.113.

De Deckere, E.A. and Korver, O. (1996): Minor constituents of rice bran oil as functional foods. Nutr. Rev., 54:120-126.

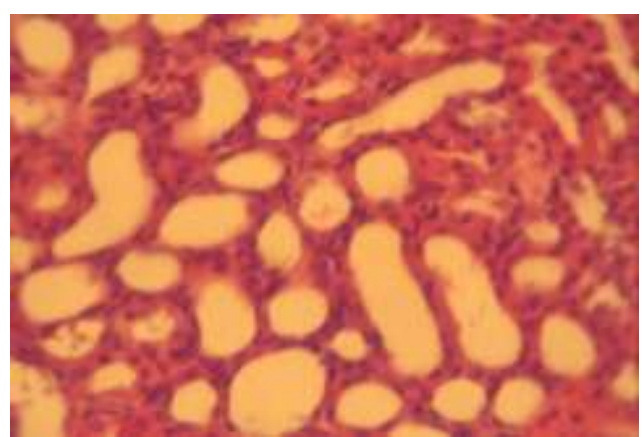

Fig. $(3, f)$ : Kidneys of rat fed diets containing $15 \%$ rice bran oil showing cystic dilatation of the renal tubules in the medulla. (H\&E stain X600)

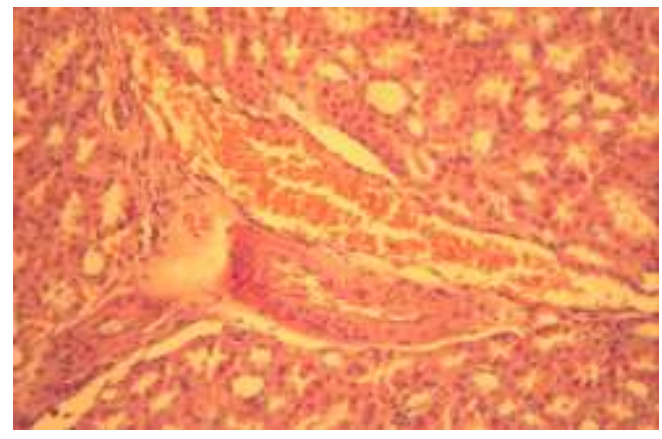

Fig. (3,h): Kidneys of rat fed diets containing $25 \%$ and $30 \%$ rice bran oil showing mild congestion of some renal blood vessels. (H\&E stain X300)

Doumas, B.T. (1975): Standard methods of protein determination. Clin. Chem., 7: 175-188.

Doumas, B.T., Waton, W.A. and Biggs, H.G. (1971): Albumin standards and measurement of serum albumin with bromocresol green. Clin. Chem. Acta., 31:87.

Drury, R. and Wallington, E. (1986): Carlton's histological technique. $4^{\text {th }}$ Ed., Oxfrd Univ. Press, N.Y., Toronto.

El-Shirbeeny, A.A., Alam, S.O. and Abd ElSalam, S.M. (2003): Effect of malt and some barley by-products as hypolipidemic agents. Conference Comi-basal. Crops Technology Department, Food Technology Reseach Institute, A.R.C. Giza, Egypt, p. 965-982.

F.A.O. and W.H.O. (1993): Fats and Oils in human nutrition. Report of a joint expert consultation organized by the Food and Agriculture Organization of the United Nations and the world Health Organization Rome, 19-26 October. 10:19-26. 
Finely, M.K. (1978): Enzymatic colorimetric determination of serum total cholesterol. Clin. Chem., 24:391.

Foda, F.A. (2005): Effect of addition of freeze dried from young green barley leaves on Hypercholesterolemic rats. Annals of Agric. Sc., Moshtohor, 43(4): 1649-1663.

Fossati, P. and Preceipe, L. (1982): The determination of triglyceride using enzymatic methods. Clin. Chem., 28:2077.

Ha, T., Han, S., Kim, S., Kim, I., Lee, H. and Kim, H. (2005): Bioactive components in rice bran oil improve lipid profiles in rats fed a highcholesterol diet. Nutr. Res., 25:597-606.

Hassan, S.H., Abu-AR, S.A. and Roushdy, H.M. (1994): Possible role of the antipsychotic drug "fluphenazine" against post-irradiation injury in rats. Egypt. J. Rad. Sci. Applic., 7(2):181.

Hegsted, M. and Kousik, E.S. (1994): Rice bran and rice bran oil may lower heart disease risk by decreasing cholesterol synthesis in the body. Louisiana Agric., 37(2):16-17.

Heibashey, M.I. and Abdel-Moneim, A.E. (1999): Kidney and liver function tests after late dimethyl sulfoxide (DMSO) administration in rats with gentamicin induced acute renal failure. J. Egypt. GER. Soc., 30(A): 35-48.

Henery, R.J., Canon, D.C. and Wikelman, J.W. (1974): Clinical Chemistry: Principles and techniques, $2^{\text {nd }}$ Ed., New York, Harper and Row., pp. 422-424.

Lane-Peter, W. and Pearson, A.E. (1971): Dietary requirement. In "The laboratory animal principles and practice" P.142, Academic Press, London and New York.

Lopez-Virella, M.F., Stone, S., Ellis, S. and Collwel, J.A. (1977): Cholesterol determination in high density lipoproteins separated by three different methods. Clin. Chem., 23(5): 882.

Miller, G.L. (1959): Use of dinitrosalicylic acid reagent for determination of reducing sugars. Anal. Chem., 31:426-428.

Oluremi, O.I., Solomon, A.O. and Saheed, A.A. (2013): Fatty acids, metal composition and physico-chemical parameters of Igbemo Ekiti rice bran oil. J. Envir. Chem. Ecotoxicol., 5(3):39-46.

Orthoefer, F.T. (1996): Rice bran oil: healthy lipid source. Food Techn., 50:62-64.

Ramachandran, H.D. (2001): Effect of n-3 fatty acids on oxidative stress in liver and brain of rats. Ph. D thesis, University of Mysore, Mysore, India.

Reitman, S. and Frankel, S. (1957): A colorimetric method for the determination of serum glutamic oxaloacetic and glutamic pyruvic transaminases. Am. J. Clin. Path., 28:56.

Saunders, R.M. (1990): The properties of rice bran as a food stuff. Creal Fd. World., 35:632-636.

Steinberg, D. (1981): Metabolism of lipoproteins at the cellular level in relation to atherogensis. In lipoproteins, atherosclerosis and coronary heart disease. 1, 2, 31 Elsevier-North Holland.

Sugano, M. and Tsuji, E. (2003): Rice bran oil and cholesterol metabolism. J. Nutr., 8(1):22-33.

Tabassum, S., Aggarwal, S., Ali, S.M., Beg, Z.H., Khan, A.S. and Afzal, K. (2005): Effect of rice bran oil on the lipid profile of steroid responsive nephritic syndrome. Indian J. Nephrol., 15:10-13.

Tahira, R., Rehman, A.U. and Butt, M.A. (2007): Characterization of rice bran oil. J. Agric. Res., 45(3):225-230.

Tabacco, A., Searcy, R.L., and Reardson, J.E. (1979): Simplified enzymatic colorimetric serum urea nitrogen determination. Clin. Chem., 25: 336-337. 


\section{التقييم الحيوى والهستولوجى لزيت نخالة الارز على الجرزان مرتفعة مستوى الكوليسترول}

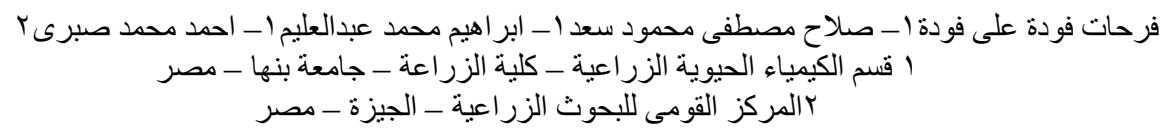

يعتبر الأرز من أهم المحاصيل الزر اعية فى العالم وتمثل نخالة الأرز ( من وزنه وهى تحتوى على العديد من البروتينات و الدهون

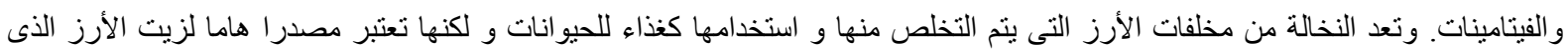
يحتوى على نسبة كبيرة من الاحماض الدهنية الغير مشبعة و العديد من المكونات التى تشكل أهمية فى النظام الغذائي و الصحة . و يهدف هذا البحث إلى تقدير المكونات الكيميائسة لنخالة الارز وكذلك دراسة الخو اصنيز الفيزيائية و الكيميائية ومكونات الاحماض الدهنية للزيت

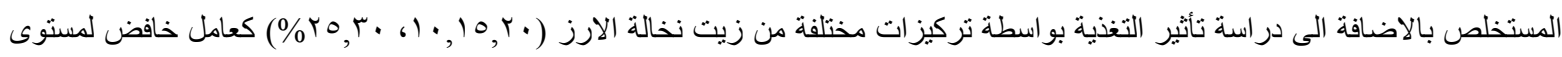
الكوليستيرول فى فئران التجارب التى تغذت على وجبة مرتفعة فى محتوى الكوليسيرول وكذلك خفض مسنوى الدهون الثلاثية فى الدم وكذلك

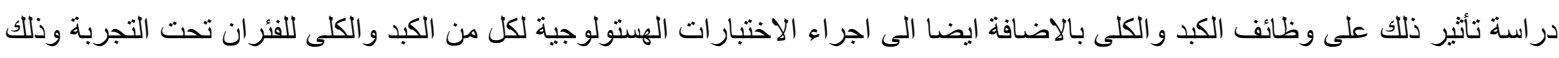
لمدة V اسابيع .

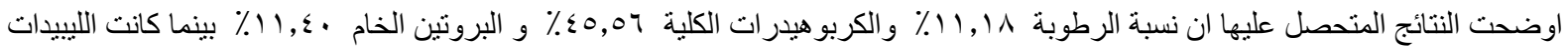

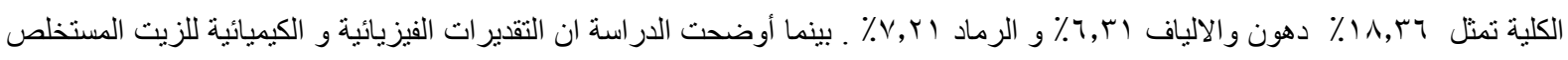

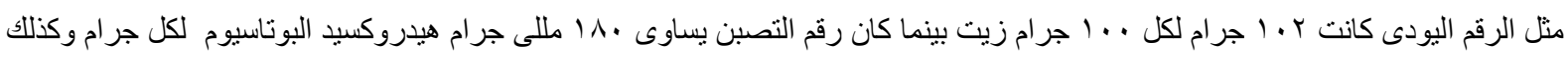

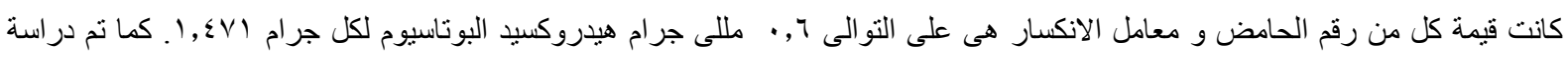

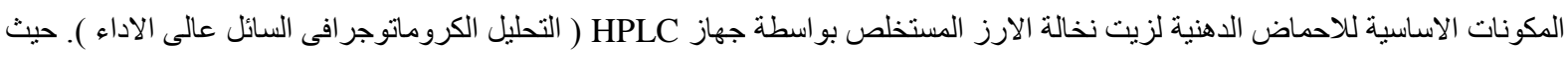

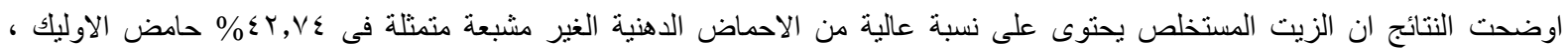

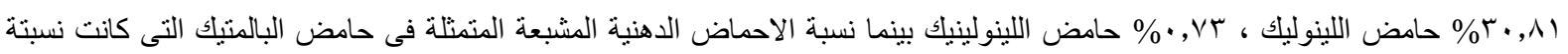

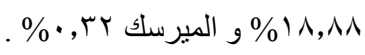
وكذلك تم اخذ عينات من الدم للجرزان تحت التجارب لتقدير الكوليستيرول الكلى والجليسريدات الثلاثية وكوليستيرول الليبوبروتينات منخفضة الكثافة ( LDL-C) و عالية الكثافة ( HDL-C ) و مذللك وظائف الكبد و الكلى. حيث اظهرت نتائج التحليل انخفاض معنوى فى التقديرات السابقة الذكربينما حدث ارتفاع فى الليبوبروتينات مرتفعة الكثافة وذللك فى المجموعات

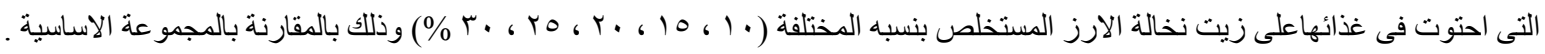

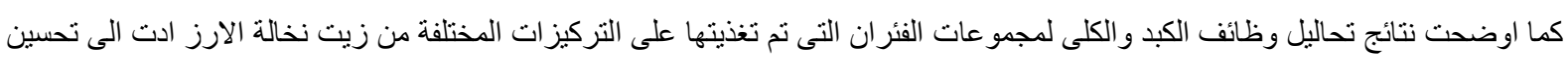
هذه الوظائف بالمقارنة بالمجمو عة عالية الكوليستيرول وقد اوضح ذللك الفحص الهستوباثولوجى لانسجة الكبد والكلى . وبذللك فانه يمكن التوصية باستخدام زيت نخالة الارز المستخلص فى الوجبات كعامل خافض لنسبة الكوليستيرول ومستوى الدهون بالدم . 